\title{
EVALUATION OF GROUNDWATER QUALITY IN PRE- MONSOON AND POST-MONSOON SEASONS OF A YEAR USING WATER QUALITY INDEX (WQI)
}

\author{
V. Dhilleswara Rao ${ }^{1, *}$, M.V. Subba Rao ${ }^{2}$ and M.P.S.Murali Krishna ${ }^{3}$ \\ ${ }^{1,2}$ Department of Chemistry, G M R Institute of Technology, Affiliated to JNTUK-Kakinada \\ Rajam, 532127, A.P, India. \\ ${ }^{3}$ Department of Chemistry, Government Polytechnic, Thadepalligudem 534101, A.P, India. \\ *E-mail: dhilleswararao.v@gmrit.edu.in
}

\begin{abstract}
Water Quality Index-WQI is useful to transfer complex information of the groundwater quality data into comprehensible and useable data. In this research work, the investigation is carried out by collecting 66 groundwater samples and amalgamating nine water quality parameters for evaluation of groundwater utilizing WQI in pre- as well as post-monsoon of a year in the villages of Gara Mandal of Srikakulam District in Andhra Pradesh. The results confirmed that most of the groundwater sample locations (54.5\% of groundwater samples) showed poor quality in both pre- as well as post-monsoon seasons. On the other hand, the correlation matrix indicates the strong positive correlation exists between the chemical parameters like calcium ion and magnesium ion with chloride, sulphate as well as nitrate ion represents that groundwater in the sampling locations has been polluted due to geological conditions, seepage of sewage and anthropogenic activities. Hence a proper treatment is required before utilized for drinking.
\end{abstract}

Keywords: Water Quality Index, Groundwater, Physicochemical parameters, correlation, Gara Mandal.

○ RASĀYAN. All rights reserved

\section{INTRODUCTION}

The earth is known as the "Blue Planet" or "Water planet. Water is nature's most common chemical compound of all living creatures and the gift of nature. Water is the best of all things and is the most wonderful, abundant and valuable resource for the existence of life on earth. ${ }^{1}$ Water is normally got from two noteworthy natural resources; superficial water, for example, freshwater from lakes and streams and groundwater from boreholes and wells. Surface and subsurface water assets are limited and subject to change as the atmosphere and ecological conditions and hence the principle resource of freshwater is groundwater. All most all about $97.2 \%$ water is salt water and $2.8 \%$ water is freshwater in this universe. Among all the water sources $20 \%$ water is available from groundwater. Groundwater is the most significant universal natural resource for the monetary improvement and secure provision of consumable water supply in both urban and rural areas. ${ }^{2,3}$ Groundwater is characterized as water that is found underneath the surface of the earth. It forms an essential portion of the water cyclic process. The water enters into the underground on account of gravity, goes through the rocks and soil until it reaches a profundity wherever the groundwater can no longer penetrate and is stored. The aquifer is an underground permeable and porous rock where the groundwater is stored. Aquifer permits the water to penetrate and permits movement inside the rock.

Moreover, all most all about 97 percent of the world's useable freshwater is put away as groundwater. The significance of groundwater is escalating exponentially to less vulnerability to surface pollution as different pollutants get chemically and biologically degraded in the unsaturated zone before reaching the groundwater table. The greater part of the world relies upon groundwater for survival and in the present situation, rapid increment in populace results in depletion of water resources. To fulfill the requirement, groundwater goes about as a major source.

Rasayan J. Chem., 12(4), 1828-1838(2019)

http://dx.doi.org/10.31788/RJC.2019.1245394

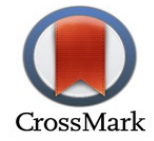


The significance of groundwater is rising exponentially to less vulnerability to surface pollution as different pollutants get chemically degraded and biologically degraded in the unsaturated zone before reaching the groundwater table. Human beings in the world are under risk because of an undesired change in the chemical, physical as well as biological characteristics of groundwater. Generally, groundwater is contaminated by anthropogenic sources like waste dumping, animal squanders, public wastewater, pesticides, upkeep spill over and manures which influence the groundwater. Also, the release of raw wastewater through bores and leachate from intuitive disposal of solid wastes, generally polluting groundwater. ${ }^{4}$

Quality of groundwater is the most important need for human beings. ${ }^{5}$ The groundwater quality is considered as an essential factor to judge environment changes which are powerfully connected with social and economic development. Seasonal variations can also affect the quality of groundwater. ${ }^{6,7}$ The monitoring of quality groundwater is one of the significant strategies for sustainable improvement and gives vital data to water supervision.

The Water Quality Index (WQI) technique can impart the water quality information ${ }^{8}$ and is normally used for the identification and evaluation of water contamination by different physicochemical parameters. ${ }^{9}$ It is a solitary number that rates the water quality by totaling different water quality parameters. ${ }^{10}$ The WQI procedure has been generally associated to evaluate both groundwater and surface water quality. From this time forward, it has ended up being the most helpful and fruitful technique for the assessment and administration of groundwater quality worldwide, particularly while considering the chance of incorporating drinking water principles generally utilized in water pollution guidelines. ${ }^{11}$

In this research article, the results were presented related to a physicochemical analysis of groundwater in the villages of Gara Mandal of Srikakulam District, Andhra Pradesh, India. The groundwater quality in the identified sample locations was carried out at seasonally as pre- as well as post-monsoon respectively in the year 2015. Based on the obtained values, the overall groundwater quality is measured by employing the WQI method.

\section{Study Area}

Gara Mandal is located 19 kilometers far from the headquarters of Srikakulam district and is close to the inlet of Bay of Bengal. In this paper, latitude in between 18.2484 to 18.4010 and the longitude in between 83.8920 to 84.9345 are taken as study range to determine the groundwater quality. Gara Mandal has expanded about 157Sq.km area and has 24 major villages. Familiar Kurmanadha temple and Salihundam Historic Buddhist places are located in Gara Mandal.

\section{Material and Methods}

\section{EXPERIMENTAL}

\section{Sample Collection and Analysis}

Totally 66 water samples (Fig.-1) were collected from chosen sites (Table-1) at pre- as well as postmonsoon in the year 2015 from wells, hand pumps and bore waters. Groundwater samples were collected in clean two-liter plastic bottles ${ }^{12}$ and preserved as per established standard methods and the analysis of water samples was carried out using analytical reagent (AR) grade chemicals. The various physicochemical parameters were analyzed as per standard methods. ${ }^{13}$ The instruments such as Digital $\mathrm{pH}$ meter (Systronics- 335 model), Nefleometer (Systronics-132 model), Digital Conductometer (Systronics306 model,), Double beam Spectrometer (Systronics-AU-2701 model), Atomic Absorption Spectrophotometer (Perkin Elmer-model 400AAS), Fluoride ion-selective electrode (Cyber scan 2100Microprocessor-based bunch PH / Ion meter) were used.

\section{Evaluation of Water Quality Index (WQI)}

WQI is determined for the quality of groundwater, as it is an important tool for the evaluation of overall groundwater quality. ${ }^{14}$ To measure the WQI, the subsequent main steps have been taken into account. In the initial step, some parameters were chosen from the determined parameters in the water samples and weightage $\left(\mathrm{w}_{\mathrm{i}}\right)$ which was taken numerically from 1 to 5 depending upon their significance in the evaluation of groundwater quality. The highest weightage of 5 has been allocated to TDS and TH and for 


\section{RASĀYAN J. Chem.}

Vol. 12 | No. 4 |1828 - 1838| October - December | 2019

other parameters, 1 to 4 has been allocated depending upon their significance in the evaluation of groundwater quality (Table 2). According to WHO-2004 standards, the desirable limit $\left(\mathrm{S}_{\mathrm{i}}\right)$ of every parameter in the groundwater samples is considered. In the next step, the relative weights $\left(\mathrm{W}_{\mathrm{i}}\right)$ of each parameter was calculated by an equation: ${ }^{15}$

$$
\mathrm{W}_{\mathrm{i}}=\frac{w i}{\sum_{i=1}^{n} w i}
$$

Where ' $\mathrm{W}_{\mathrm{i}}$ ' indicates relative weights, ' $\mathrm{w}_{\mathrm{i}}$ ' stand for the allocated weight of individual parameter and ' $\mathrm{n}$ ' represents the total number of determined parameters.

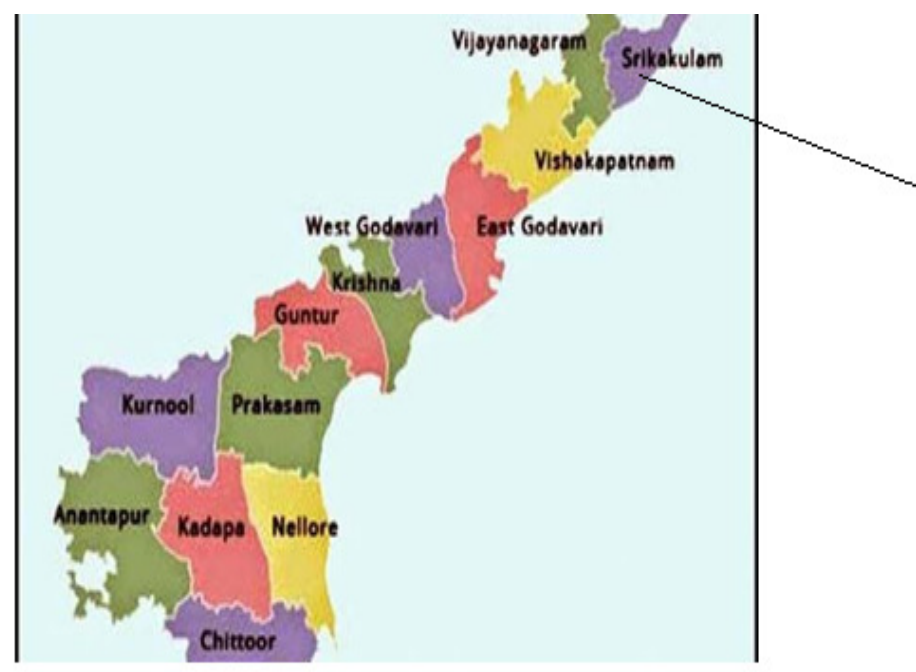

\section{Districts in Andhra Pradesh}

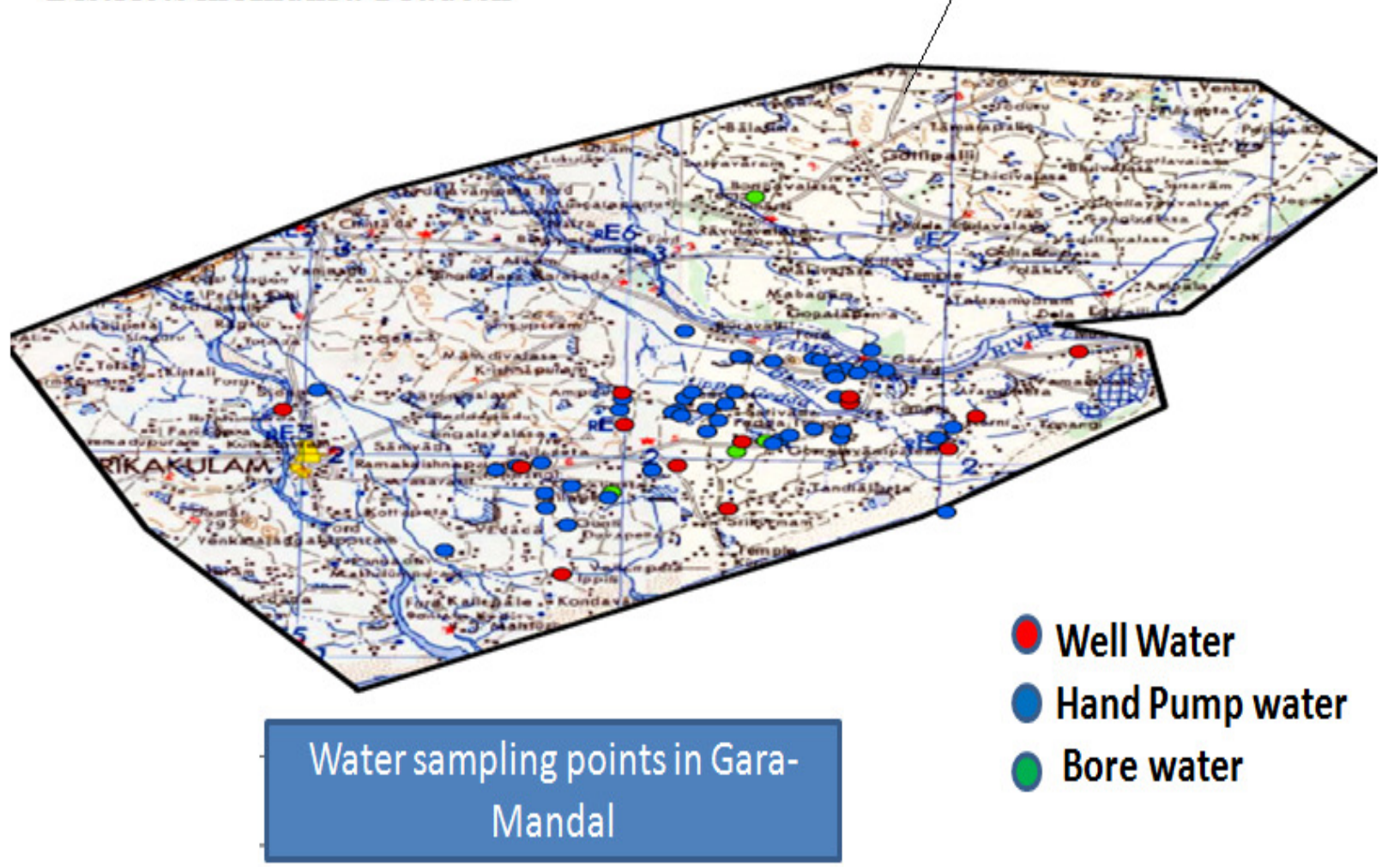

Fig.-1: Location Map and Groundwater Sample Points in Gara Mandal, Srikakulam District, Andhra Pradesh, India. 
RASĀYAN J. Chem.

Vol. 12 | No. 4 |1828 - 1838| October - December | 2019

Table-1: Ground Water Sample Location in the villages of Gara Mandal

\begin{tabular}{|c|c|c|c|c|c|c|c|c|c|}
\hline Sam.No & Location site & Source & Latitude & longitude & Sam.No & Location site & Source & Latitude & longitude \\
\hline 1 & Vatsavalasa colony & A & 18.2923 & 83.9989 & 34 & Ramachandrapuram-Domaveddi & B & 18.2906 & 83.9497 \\
\hline 2 & Vastavalasa(Muncipal Primary School) & B & 18.2905 & 83.9921 & 35 & Ramachandrapuram-near Rama temple & B & 18.2935 & 83.9621 \\
\hline 3 & Vatsavalasa-House & $\mathrm{C}$ & 18.2815 & 83.9812 & 36 & Simmaveta Junction & A & 18.2917 & 83.9566 \\
\hline 4 & Amadalapadu-vatsavalsa Panchayati office) & $\mathrm{C}$ & 18.3023 & 84.0230 & 37 & Deepavali-Bus stand Street & B & 18.2840 & 83.9702 \\
\hline 5 & Pedatulugu -Segidiveedi & B & 18.3034 & 84.0430 & 38 & Deepavali-Primary School & B & 18.2812 & 83.9630 \\
\hline 6 & Peddatulugu-Gollaveedi & B & 18.3063 & 84.0437 & 39 & Deepavali- Sondipeta (Sai baba temple) & B & 18.2683 & 83.9691 \\
\hline 7 & Chinnatulugu Main road & A & 18.3175 & 84.0456 & 40 & Deepavali- Lankapeta( shiva temple) & B & 18.2794 & 83.9802 \\
\hline 8 & Chinnatulugu -Muncipal primary school & B & 18.3071 & 84.0359 & 41 & Gonti-Entrance & B & 18.2752 & 83.9633 \\
\hline 9 & Nizamabad-Road point & B & 18.3028 & 84.0268 & 42 & Sunkarapalem & A & 18.2484 & 83.9676 \\
\hline 10 & Nizamabad-Kaalingapeta road point & B & 18.3012 & 84.0249 & 43 & Jalluvalasa-SC colony & B & 18.3202 & 84.0420 \\
\hline 11 & Nizamabad-SC colony & $\mathrm{C}$ & 18.2980 & 84.0150 & 44 & Jalluvalasa (Anjanaya temple) & B & 18.3184 & 84.0456 \\
\hline 12 & Nizamabad-Primary school & B & 18.3046 & 84.0294 & 45 & Jalluvalasa (Anjanaya temple) & A & 18.3201 & 84.0456 \\
\hline 13 & Sattivada-Main road Point & B & 18.3196 & 84.0009 & 46 & Komi( Anjanaya temple) & B & 18.3389 & 84.0515 \\
\hline 14 & Sattivada- Rama Temple & A & 18.3020 & 84.0165 & 47 & Korni(Srisainaveedi) & A & 18.3122 & 84.0799 \\
\hline 15 & Sattivada-Pedalapur Street & $\mathrm{C}$ & 18.4010 & 84.0200 & 48 & Korni-SC colony & B & 18.3078 & 84.0736 \\
\hline 16 & Sattivada-Gangu Street & B & 18.3106 & 84.0100 & 49 & Korni-SC colony & A & 18.3384 & 84.1077 \\
\hline 17 & Raghavapuram- Near anjanaya swamy temple & B & 18.3220 & 84.0145 & 50 & Korlam-Main road & B & 18.3035 & 84.0693 \\
\hline 18 & Raghvapuram -Mangala street -school & B & 18.3152 & 84.0071 & 51 & Korlam Main Road (anadarao house) & B & 18.2735 & 84.0718 \\
\hline 19 & Raghavapuram-SC-colony & B & 18.3061 & 84.0070 & 52 & Korlam (Anjanaya temple) & A & 18.2991 & 84.0724 \\
\hline 20 & Syrigam -Polaki Street & B & 18.3147 & 83.9990 & 53 & Gara-Primary school & B & 18.3308 & 84.0554 \\
\hline 21 & Syrigam -Grama Panchayati Office & B & 18.3139 & 83.9977 & 54 & Gara-Secondary school & B & 18.3325 & 84.0513 \\
\hline 22 & Syrigam-Sai ram temple Arangipeta & B & 18.3125 & 84.0000 & 55 & Gara-Boravanipeta bus stand primary & B & 18.3317 & 84.0442 \\
\hline 23 & Rama krishnapuram-Road point & B & 18.3172 & 84.0120 & 56 & Salihundam Board & B & 18.3298 & 84.0479 \\
\hline 24 & Rama krishnapuram-Primary School & B & 18.3220 & 84.0029 & 57 & Garakothapetta -Primary school & B & 18.3297 & 84.0410 \\
\hline 25 & Ampolu Colony & B & 18.3149 & 83.9833 & 58 & Kothapetta Primary school & B & 18.3310 & 84.0410 \\
\hline 26 & Ampolu bus stand street - panchayati office & A & 18.3218 & 83.9839 & 59 & Salihundam Primary school & B & 18.3356 & 84.0357 \\
\hline 27 & Ampolu-kothapeta & A & 18.3089 & 83.9845 & 60 & Salihundam SC colony & B & 18.3350 & 84.0378 \\
\hline 28 & Ampolu-kothapeta & B & 18.3194 & 83.9841 & 61 & Konkenapetta -Salihundam & B & 18.3281 & 84.0419 \\
\hline 29 & Reddy peta & B & 18.3229 & 83.9014 & 62 & Kolluvalasa(near srirama temple) & A & 18.2749 & 84.0126 \\
\hline 30 & Reddy peta & A & 18.3150 & 83.8920 & 63 & Kollivalasa & B & 18.3345 & 84.0248 \\
\hline 31 & Vadada-Pangala street & B & 18.2683 & 84.9345 & 64 & Ambalavalsa-Jonnadaveedi & B & 18.3362 & 84.0167 \\
\hline 32 & Vadada-Chipiri veedi & B & 18.2581 & 83.9358 & 65 & Ambalavalsa-Anjanaya temple & B & 18.3364 & 84.0157 \\
\hline \multirow[t]{2}{*}{33} & Ranachandrapuram-Primary school & B & 18.2924 & 83.9555 & 66 & Booravelli-Ammavari temple & B & 18.3467 & 84.0010 \\
\hline & \multicolumn{9}{|c|}{$A=$ Well water, $B=$ Hand pump and $C=$ Bore water } \\
\hline
\end{tabular}

Subsequently, a quality rating scale $\left(\mathrm{Q}_{\mathrm{i}}\right)$ is measured for every parameter by the equation:

$$
\mathrm{Q}_{\mathrm{i}}=\frac{c_{\mathrm{i}}}{s_{\mathrm{i}}} * \mathbf{1 0 0}
$$

Where ' $\mathrm{C}_{\mathrm{i}}$ ' is the concentration of the determined parameter in each water sample. ' $\mathrm{S}_{\mathrm{i}}$ ' represents the standard value, according to the WHO-2004 standards.

Lastly, the WQI is measured with an equation: $\mathrm{WQI}=\Sigma W_{\mathrm{i}} \times \mathrm{Q}_{\mathrm{i}}$

here ' $\mathrm{W}_{\mathrm{i}}$ ' indicates the relative weights of each determined parameter and ' $\mathrm{Q}_{\mathrm{i}}$ ' indicates the quality rating scale. Following the WQI values, the groundwater is represented into five categories as shown in Table-3. 
RASĀYAN J. Chem.

Vol. 12 | No. 4 |1828 - 1838| October - December | 2019

Table-2: Assigned Weights and Relative Weights of Analyzed Parameters in the Groundwater Samples and Standard Values Given by WHO (2004)

\begin{tabular}{c|c|c|c|c}
\hline S.No. & Chemical Parameter & Weight $\left(\mathrm{w}_{\mathrm{i}}\right)$ & $\begin{array}{c}\text { WHO } \\
\text { Standards }\left(\mathrm{S}_{\mathrm{i}}\right)\end{array}$ & $\begin{array}{c}\text { Relative weights } \\
\left(\mathrm{W}_{\mathrm{i}}\right)\end{array}$ \\
\hline 1 & Total Dissolved Solids & 5 & 500 & 0.1612 \\
\hline 2 & Total Hardness & 5 & 300 & 0.1612 \\
\hline 3 & Chloride & 4 & 250 & 0.1290 \\
\hline 4 & Fluoride & 4 & 1.5 & 0.1290 \\
\hline 5 & Total Alkalinity & 3 & 200 & 0.0967 \\
\hline 6 & Calcium & 2 & 75 & 0.0645 \\
\hline 7 & Magnesium & 2 & 50 & 0.0645 \\
\hline 8 & Sodium & 4 & 200 & 0.1290 \\
\hline 9 & Potassium & 2 & 12 & 0.0645 \\
\hline & & $\sum \mathrm{wi}=31$ & & \\
\hline
\end{tabular}

Table-3: Identification of the Category of Water of Groundwater Samples Collected From the Study Area Using WQI Range in Pre-Monsoon and Post-Monsoon Periods

\begin{tabular}{|c|c|c|c|c|c|}
\hline \multicolumn{2}{|c|}{$\begin{array}{l}\text { WQI Range } \\
\text { Category }\end{array}$} & \multicolumn{2}{|c|}{ Pre-Monsoon } & \multicolumn{2}{|c|}{ Post-Monsoon } \\
\hline$<50$ & $\begin{array}{l}\text { Excellent } \\
\text { Water }\end{array}$ & $\begin{array}{l}\text { Water Sample } \\
\text { Numbers } \\
53,54,56,57,61\end{array}$ & $\begin{array}{l}\text { \% category of } \\
\text { Groundwater } \\
\text { Quality } \\
7.57 \%\end{array}$ & $\begin{array}{l}\text { Water Sample Numbers } \\
53,54,61\end{array}$ & $\begin{array}{l}\text { \% category of } \\
\text { Groundwater Quality } \\
4.54 \%\end{array}$ \\
\hline $\begin{array}{c}50.1- \\
100\end{array}$ & $\begin{array}{l}\text { Good } \\
\text { Water }\end{array}$ & $\begin{array}{l}3,11,13,14,23,24,25 \\
, 29,39,40,45,46,50, \\
58,59,62,63\end{array}$ & $25.75 \%$ & $\begin{array}{l}3,11,13,14,23,24,25,29,3 \\
9,40,45,46,50,56,57,58,5 \\
9,62,63\end{array}$ & $28.78 \%$ \\
\hline $\begin{array}{c}100.1- \\
200\end{array}$ & Poor Water & $\begin{array}{l}1,2,4,6,7,9,12,15,16 \\
19,21,22,26,27,28, \\
30,31,32,33,34,35,3 \\
6,37,38,42,43,44,48 \\
49,51,52,55,60,64, \\
65,66\end{array}$ & $54.54 \%$ & $\begin{array}{l}1,2,4,6,7,9,12,15,16,19,2 \\
1,22,26,27,28,30,31,32,3 \\
3,34,35,36,37,38,42,43,4 \\
4,48,49,51,52,55,60,64,6 \\
5,66\end{array}$ & $54.54 \%$ \\
\hline $\begin{array}{c}200.1- \\
300\end{array}$ & $\begin{array}{c}\text { Very Poor } \\
\text { Water }\end{array}$ & $5,8,10,17,18,20,41$ & $10.6 \%$ & $5,8,10,17,18,20,41,47$ & $12.14 \%$ \\
\hline$>300.1$ & $\begin{array}{l}\text { Unfit for } \\
\text { Water }\end{array}$ & 47 & $1.51 \%$ & --- & --- \\
\hline
\end{tabular}

\section{RESULTS AND DISCUSSION}

\section{Groundwater Quality in the Study Region}

The obtained results related to pre- as well as post-monsoon seasons, are explained here by the following parameters. The statistical analysis of groundwater samples of pre- as well as post-monsoon, were presented in Table-4 and Table-5. The number of water samples exceeds the acceptable limit prescribed by BIS-2012 and WHO-2004 of each parameter in pre- as well as post-monsoon was presented in Table6.

\section{Turbidity and pH}

Turbidity is caused by algae, particles of soil, metals, organic matter, suspended and inorganic matter in the water. There turbidity values in all places in pre- and post-monsoon were the negligible amount. There is a considerable change in the $\mathrm{pH}$ value during pre- as well as post-monsoon and the $\mathrm{pH}$ values obtained from 6.24 to 8.51 in the pre-monsoon whereas 6.32 to 8.12 in the post-monsoon. The majority of the water samples having a high $\mathrm{pH}$ in pre-monsoon and it might be due to the high temperature in premonsoon. Except sample number-8 remaining all water samples having $\mathrm{pH}$ values were in permissible limit according to BIS-2012. ${ }^{16}$ 
RASĀYAN J. Chem.

Vol. 12 | No. 4 | 1828 - 1838| October - December | 2019

\section{Electrical Conductivity (EC) and Total Alkalinity (TA)}

EC is a vital factor for representing the quality of groundwater and it indicates a salinity risk. High conductivity might arise from anthropogenic sources and natural weathering. EC value during pre- as well as post-monsoon periods, were in the range of 291-6350 (u mhos $/ \mathrm{cm})$ and 332-5786 $(\mathrm{u} \mathrm{mhos} / \mathrm{cm})$ respectively. Majority of the water samples have high EC values during pre- as well as post-monsoon representing the presence of more amounts of dissolved salts present in groundwater samples in an ionized state. Metabolic alkalosis is caused by excess intake of high alkalinity containing water. The Total alkalinity obtained from $71 \mathrm{mg} \mathrm{l}^{-1}$ to $525 \mathrm{mg} \mathrm{l}^{-1}$ and $78 \mathrm{mg} \mathrm{l}^{-1}$ to $519 \mathrm{mg} \mathrm{l}^{-1}$ in the pre and post-monsoon respectively. 51 out of 66 groundwater samples were exceeding than desirable limit according to BIS2012.

\section{Total Dissolved Solids (TDS) and Total Hardness (TH)}

The TDS stands for the mixture of inorganic minerals (mainly calcium, magnesium, sodium and potassium salts of sulphates, chlorides, and bicarbonates) and little amount of organic components. The TDS obtained from $190 \mathrm{mg} \mathrm{l}^{-1}$ to $4062 \mathrm{mg} \mathrm{l}^{-1}$ and $212 \mathrm{mg} \mathrm{l}^{-1}$ to $3701 \mathrm{mg} \mathrm{l}^{-1}$ in pre- as well as post-monsoon respectively. The observed TDS results demonstrate that the majority of the groundwater samples were identified as excess than desirable limits when compared with BIS-2012 standards. The TH in groundwater is mostly owing to the occurrence of calcium and magnesium salts. The TH obtained from $130 \mathrm{mg} \mathrm{l}^{-1}$ to $1618 \mathrm{mg} \mathrm{l}^{-1}$ and $105 \mathrm{mg}^{-1}$ to $1550 \mathrm{mg} \mathrm{l}^{-1}$ in pre- as well as post-monsoon respectively. There is no drastic difference in the concentrations of total hardness, calcium as well as magnesium ions in preas well as post-monsoon. The number of water samples exceeds the acceptable limit prescribed by BIS2012 and WHO-2004 of TDS and TH in pre- as well as post-monsoon seasons were shown in Table-6.

\section{Calcium $\left(\mathrm{Ca}^{2+}\right)$ and Magnesium $\left(\mathrm{Mg}^{2+}\right)$ Hardness}

$\mathrm{Ca}^{2+}$ and $\mathrm{mg}^{2+}$ ions are important minerals and helpful to the health of humans in several aspects. ${ }^{9}$ Insufficient intake of these ions is capable of imparting adverse health effects. The more intake of calcium can impede the quality of groundwater by causing kidney or bladder stone development, disturbance in urinary section in human beings, encrustation. ${ }^{17}$ High intake of $\mathrm{Mg}^{2+}$ concentration may cause purgative impact while its deficiency impacts structural and utilitarian changes and is not suitable for the domestic point of view. The $\mathrm{Ca}^{2+}$ concentration obtained from $26 \mathrm{mg} \mathrm{l}^{-1}$ to $309 \mathrm{mg} \mathrm{l}^{-1}$ and $22 \mathrm{mg} \mathrm{l}^{-1}$ to $310 \mathrm{mg} \mathrm{l}^{-1}$ in pre- as well as post-monsoon respectively. The $\mathrm{Mg}^{2+}$ concentration obtained from $14 \mathrm{mg} \mathrm{l}^{-1}$ to $253 \mathrm{mg} \mathrm{l}^{-1}$ and $12 \mathrm{mg} \mathrm{l}^{-1}$ to $245 \mathrm{mg} \mathrm{l}^{-1}$ in pre- as well as post-monsoon respectively. There is no drastic difference in the concentrations of calcium and magnesium hardness in pre- as well as post-monsoon. The number of water samples exceeds the acceptable limit prescribed by BIS-2012 and WHO-2004 of calcium and magnesium ions in pre-monsoon as well as post-monsoon was presented in Table-6.

\section{Sodium $\left(\mathrm{Na}^{+}\right)$and Potassium $\left(\mathrm{K}^{+}\right)$}

The sodium $\left(\mathrm{Na}^{+}\right)$ion is highly soluble in groundwater and it is a normal constituent of the body and adequate levels of $\mathrm{Na}^{+}$are wanted for better health. ${ }^{18}$ Potassium $\left(\mathrm{K}^{+}\right)$ion is an essential constituent in humans. It is a fundamental supplement; however, if it is excess, might act as a laxative. $\mathrm{Na}^{+}$ion concentration is obtained from $10 \mathrm{mg} \mathrm{l}^{-1}$ to $267 \mathrm{mg} \mathrm{l}^{-1}$ and $12 \mathrm{mg} \mathrm{l}^{-1}$ to $254 \mathrm{mg} \mathrm{l}^{-1}$ in pre- as well as postmonsoon respectively. The $\mathrm{K}^{+}$ion concentration is obtained from $0.2 \mathrm{mg} \mathrm{l}^{-1}$ to $120 \mathrm{mg} \mathrm{l}^{-1}$ and $0.82 \mathrm{mg}^{-1}$ to $112 \mathrm{mg} \mathrm{l}^{-1}$ in pre- as well as post-monsoon respectively. There is a slight difference in the concentrations of sodium $\left(\mathrm{Na}^{+}\right)$, potassium $\left(\mathrm{K}^{+}\right)$ion in pre- as well as post-monsoon. The number of water samples exceeds the acceptable limit prescribed by BIS-2012 and WHO-2004 of sodium and potassium ions in pre- as well as post-monsoon was presented in Table-6.

\section{Fluoride $\left(\mathrm{F}^{-}\right)$and Chloride $\left(\mathrm{Cl}^{-}\right)$}

Fluoride is essential to human beings at low levels and it helps to avoid the tooth rot in children. The excessive intake of high fluoride contained water with a long period can bring about health problems like softening of bones, mottling of teeth, dental fluorosis and different neurologic harms. Chloride is a necessary electrolyte mineral which keeps the quantity of a cell fluid inside and around in a balancing way. It also keeps up appropriate blood volume and pressure of a cell. The Fluoride $\left(\mathrm{F}^{-}\right)$ion is obtained from $24 \mathrm{mg} \mathrm{l}^{-1}$ to $547 \mathrm{mg} \mathrm{l}^{-1}$ and $0.12 \mathrm{mg} \mathrm{l}^{-1}$ to $1.34 \mathrm{mg} \mathrm{l}^{-1}$ in pre- as well as post-monsoon. The chloride 
RASĀYAN J. Chem.

Vol. 12 | No. 4 |1828 - 1838| October - December | 2019

$\left(\mathrm{Cl}^{-}\right)$ion is obtained from $77 \mathrm{mg} \mathrm{l}^{-1}$ to $1230 \mathrm{mg} \mathrm{l}^{-1}$ and $76 \mathrm{mg} \mathrm{l}^{-1}$ to $1226 \mathrm{mg} \mathrm{l}^{-1}$ in pre- as well as postmonsoon respectively. There is no drastic difference in the concentrations of $\mathrm{F}^{-}$and $\mathrm{Cl}^{-}$ion in premonsoon as well as post-monsoon seasons. The number of water samples exceeds the acceptable limit prescribed by BIS-2012 and WHO-2004 of fluoride and chloride ions in pre- as well as post-monsoon were presented in Table- 6 .

\section{Sulphate $\left(\mathrm{SO}_{4}{ }^{2-}\right)$ and Nitrate $\left(\mathrm{NO}_{3}{ }^{-}\right)$}

A few soils and rocks generally contain sulfate minerals. Normally groundwater travels through soils and rocks a part of the sulphate- containing minerals are dissolved. The higher amount of sulphate with calcium and magnesium in the groundwater that we consume can have a diuretic impact. Sulphate gives a severe or therapeutic taste to water if it exceeds a concentration of $250 \mathrm{mg} \mathrm{l}^{-1}$. The amount of Nitrate in groundwater is a perfect indicator of anthropogenic contamination particularly it demonstrates contributions of fertilizer used in the agricultural fields. The sulphate $\left(\mathrm{SO}_{4}{ }^{2-}\right)$ ion is obtained from 24 $\mathrm{mg} \mathrm{l}^{-1}$ to $547 \mathrm{mg} \mathrm{l}^{-1}$ and $29 \mathrm{mg} \mathrm{l}^{-1}$ to $553 \mathrm{mg} \mathrm{l}^{-1}$ in pre- as well as post-monsoon. The nitrate $\left(\mathrm{NO}_{3}{ }^{-}\right)$ion is obtained from $9 \mathrm{mg} \mathrm{l}^{-1}$ to $73 \mathrm{mg} \mathrm{l}^{-1}$ and $11 \mathrm{mg} \mathrm{l}^{-1}$ to $73 \mathrm{mg} \mathrm{l}^{-1}$ in pre- as well as post-monsoon and the samples exceed than the BIS-standards were shown in Table-6.

\section{Iron $\left(\mathrm{Fe}^{2+}\right)$, Manganese $\left(\mathrm{Mn}^{2+}\right)$ and $\mathrm{Chromium}\left(\mathrm{Cr}^{6+}\right)$}

Iron is a generally found in earth's crust. Iron is biologically an essential element which is important to all living organisms and is present in haemoglobin. Iron and manganese are minerals mostly found in groundwater and essential nutrients. High amounts of manganese can cause toxic neurological effects in human beings, psychological disorders, hyposexuality. The chromium metal exits in the form of hexavalent $\left(\mathrm{Cr}^{6+}\right)$ and trivalent $\left(\mathrm{Cr}^{3+}\right)$ in water. $\mathrm{Cr}^{6+}$ is considered more hazardous mainly due to its carcinogenic nature. The iron $\left(\mathrm{Fe}^{2+}\right)$ ion is obtained from $0.001 \mathrm{mg} \mathrm{l}^{-1}$ to $0.37 \mathrm{mg} \mathrm{l}^{-1}$ and $0.001 \mathrm{mg} \mathrm{l}^{-1}$ to $0.38 \mathrm{mg} \mathrm{l}^{-1}$ in pre- as well as post-monsoon respectively in the groundwater samples. The manganese $\left(\mathrm{Mn}^{2+}\right)$ ion was found to be in the range of $0.001 \mathrm{mg} \mathrm{l}^{-1}$ to $0.37 \mathrm{mg} \mathrm{l}^{-1}$ and $0.001 \mathrm{mg} \mathrm{l}^{-1}$ to $0.38 \mathrm{mg} \mathrm{l}^{-1}$ in pre- as well as post-monsoon respectively. $\mathrm{The}^{\mathrm{Cr}^{6+}}$ is obtained from 0.0002 to $0.232 \mathrm{mg} \mathrm{l}^{-1}$ and 0.0003 to $0.678 \mathrm{mg} \mathrm{l}^{-1}$ in pre- as well as post-monsoon. The number of water samples exceeds the acceptable limit prescribed by BIS-2012 and WHO-2004 of iron $\left(\mathrm{Fe}^{2+}\right)$, manganese $\left(\mathrm{Mn}^{2+}\right)$ and chromium $\left(\mathrm{Cr}^{6+}\right)$ ions in pre- as well as post-monsoon were presented in Table- 6 .

Table-4: Statistical Analysis in Pre-Monsoon

\begin{tabular}{|c|c|c|c|c|c|c|c|c|c|c|}
\hline & $\mathrm{pH}$ & EC & Turb. & TDS & $\mathrm{TH}$ & $\mathrm{Ca}^{2+}$ & $\mathrm{Mg}^{2+}$ & $\mathrm{Na}^{+}$ & $\mathrm{K}^{+}$ & TA \\
\hline Mean & 7.01 & 1596 & 0.064 & 1020.3 & 578.9 & 110 & 70.0 & 85.0 & 25.6 & 270.1 \\
\hline variance & 0.09 & 1181903 & 0.003 & 483764 & $\begin{array}{c}11291 \\
5\end{array}$ & 3855 & 2460 & 4381 & 1032 & 10324 \\
\hline SD & 0.31 & 1087 & 0.05 & 695.53 & 336.02 & 62.0 & 49.6 & 66.1 & 32.1 & 101.6 \\
\hline Skewness & 1.35 & 1.795 & 1.95 & 1.79 & 1.0 & 0.97 & 1.41 & 1.26 & 1.62 & -0.06 \\
\hline kurtosis & 7.07 & 4.622 & 5.22 & 4.61 & 0.793 & 0.65 & 2.27 & 0.69 & 1.53 & 0.009 \\
\hline Median & 7.01 & 1356 & 0.05 & 867 & 517 & 97 & 56.5 & 67 & 13.0 & 284 \\
\hline \multirow[t]{2}{*}{ Mode } & 6.95 & 1354 & 0.05 & 684 & 241 & 76 & 36 & 69 & \multirow[t]{2}{*}{2.3} & \multirow[t]{2}{*}{284} \\
\hline & $\mathrm{F}^{-}$ & $\mathrm{Cl}^{-}$ & $\mathrm{SO}_{4}{ }^{2-}$ & $\mathrm{NO}_{3}^{-}$ & $\mathrm{Fe}^{2+}$ & $\mathrm{Mn}^{2+}$ & $\mathrm{Cr}^{6+}$ & & & \\
\hline Mean & 0.487 & 280.4 & 188 & 33.4 & 0.1063 & 0.0224 & 0.021 & \multirow{7}{*}{\multicolumn{3}{|c|}{$\begin{array}{c}\text { Note: } \\
\text { Turb. = Turbidity, } \\
\text { TDS = Total Dissolved } \\
\text { Solids, } \\
\text { TH= Total Hardness }\end{array}$}} \\
\hline variance & 0.109 & 45363 & 17688 & 276 & 0.011 & 0.0015 & 0.001 & & & \\
\hline SD & 0.330 & 212.9 & 132 & 16.6 & 0.1072 & 0.0390 & 0.032 & & & \\
\hline Skewness & 1.1 & 1.863 & 1.24 & 0.999 & 1.072 & 1.9116 & 4.548 & & & \\
\hline kurtosis & 0.562 & 4.821 & 1.075 & 0.52 & 0.0223 & 2.4340 & 27.48 & & & \\
\hline Median & 0.42 & 192.5 & 154 & 30 & 0.078 & 0.0030 & 0.009 & & & \\
\hline Mode & 0.44 & 677 & 232 & 24 & 0.009 & 0.0003 & 0.004 & & & \\
\hline
\end{tabular}


RASĀYAN J. Chem.

Vol. 12 | No. 4 |1828 - 1838| October - December | 2019

Table-5: Statistical Analysis in Post-Monsoon

\begin{tabular}{|c|c|c|c|c|c|c|c|c|c|c|}
\hline & $\mathrm{pH}$ & $\mathrm{EC}$ & Turb. & TDS & $\mathrm{TH}$ & $\mathrm{Ca}^{2+}$ & $\mathrm{Mg}^{2+}$ & $\mathrm{Na}^{+}$ & $\mathrm{K}^{+}$ & TA \\
\hline Mean & 7.03 & 1577 & 0.073 & 1009.0 & 574.3 & 111 & 71.5 & 87.4 & 24.3 & 267.0 \\
\hline Variance & 0.06 & 1014287 & 0.003 & 415260 & 105451 & 3752 & 2320 & 3940 & 854 & 9381.4 \\
\hline SD & 0.25 & 1007 & 0.057 & 644.40 & 323.73 & 61.2 & 48.1 & 62.7 & 29.2 & 96.85 \\
\hline Skewness & 0.35 & 1.667 & 1.857 & 1.665 & 1.000 & 0.99 & 1.31 & 1.33 & 1.63 & 0.064 \\
\hline Kurtosis & 4.77 & 3.778 & 5.369 & 3.770 & 0.724 & 0.75 & 1.88 & 0.83 & 1.60 & 0.137 \\
\hline Median & 7.1 & 1427 & 0.06 & 913.5 & 514.5 & 99 & 60.0 & 70 & 12.7 & 272 \\
\hline \multirow[t]{2}{*}{ Mode } & 7.12 & 1102 & 0.02 & 375 & 1080 & 81 & 41 & 78 & 4.1 & 289 \\
\hline & $\mathrm{F}^{-}$ & $\mathrm{Cl}^{-}$ & $\mathrm{SO}_{4}{ }^{2-}$ & $\mathrm{NO}_{3}^{-}$ & $\mathrm{Fe}^{2+}$ & $\mathrm{Mn}^{2+}$ & $\mathrm{Cr}^{6+}$ & & & \\
\hline Mean & 0.502 & 281.6 & 189 & 30.8 & 0.104 & 0.021 & 0.059 & \multirow{7}{*}{\multicolumn{3}{|c|}{$\begin{array}{c}\text { Note: } \\
\text { Turb. = Turbidity, } \\
\text { TDS = Total Dissolved } \\
\text { Solids, } \\
\text { TH= Total Hardness }\end{array}$}} \\
\hline Variance & 0.088 & 43284 & 16039 & 262 & 0.010 & 0.001 & 0.020 & & & \\
\hline SD & 0.297 & 208.0 & 126 & 16.2 & 0.102 & 0.037 & 0.144 & & & \\
\hline Skewness & 1.07 & 1.91 & 1.121 & 0.934 & 0.903 & 2.070 & 3.002 & & & \\
\hline Kurtosis & 0.583 & 5.253 & 0.901 & 0.325 & -0.21 & 3.126 & 8.179 & & & \\
\hline Median & 0.42 & 128 & 161 & 28.5 & 0.07 & 0.004 & 0.009 & & & \\
\hline Mode & 0.41 & 677 & 123 & 18 & 0.103 & 0.000 & 0.003 & & & \\
\hline
\end{tabular}

Table-6: The Number of Water Samples of each Parameter exceeds the Acceptable Limit Prescribed by BIS-2012 and WHO-2004 in Pre-Monsoon and Post-Monsoon in the Study Region

\begin{tabular}{|c|c|c|c|c|c|c|}
\hline \multirow[t]{2}{*}{ Parameters } & \multirow[t]{2}{*}{$\begin{array}{c}\text { BIS-2012- } \\
\text { (Acceptable } \\
\text { Limit) } \\
\end{array}$} & \multicolumn{2}{|c|}{$\begin{array}{c}\text { Number of Samples } \\
\text { exceed than BIS-2012 } \\
\text { (Acceptable Limit) }\end{array}$} & \multirow[t]{2}{*}{$\begin{array}{c}\text { WHO-2004 - } \\
\text { (Acceptable } \\
\text { Limit) } \\
\end{array}$} & \multicolumn{2}{|c|}{$\begin{array}{l}\text { Number of Samples exceed } \\
\text { than WHO-2004 (Acceptable } \\
\text { Limit) }\end{array}$} \\
\hline & & $\begin{array}{c}\text { Pre- } \\
\text { monsoon }\end{array}$ & $\begin{array}{c}\text { Post- } \\
\text { monsoon }\end{array}$ & & Pre-monsoon & $\begin{array}{c}\text { Post- } \\
\text { monsoon }\end{array}$ \\
\hline $\mathrm{pH}$ & $6.5-8.5$ & 1 & --- & $6.5-8.5$ & 1 & --- \\
\hline Turbidity & 1.00 & --- & --- & 1.00 & --- & --- \\
\hline $\mathrm{EC}$ & --- & --- & --- & 1500 & 25 & 21 \\
\hline Total Alkalinity & 200 & 51 & 51 & 200 & 51 & 51 \\
\hline TDS & 500 & 49 & 49 & 500 & 49 & 49 \\
\hline Total Hardness & 200 & 60 & 61 & 300 & 48 & 50 \\
\hline Calcium $\left(\mathrm{Ca}^{2+}\right)$ & 75 & 45 & 44 & 75 & 45 & 44 \\
\hline Magnesium $\left(\mathrm{Mg}^{2+}\right)$ & 30 & 51 & 50 & 50 & 36 & 38 \\
\hline Sodium $\left(\mathrm{Na}^{+}\right)$ & ---- & --- & --- & 200 & 7 & 7 \\
\hline $\operatorname{Potassium}\left(\mathrm{K}^{+}\right)$ & ---- & --- & --- & 12 & 40 & 38 \\
\hline Fluoride $\left(\mathrm{F}^{-}\right)$ & 1 & 7 & 5 & 1.5 & -- & -- \\
\hline Chloride $\left(\mathrm{Cl}^{-}\right)$ & 250 & 24 & 24 & 250 & 24 & 24 \\
\hline Sulphate $\left(\mathrm{SO}_{4}{ }^{2-}\right)$ & 200 & 26 & 25 & 200 & 26 & 25 \\
\hline Nitrate $\left(\mathrm{NO}_{3}{ }^{-}\right)$ & 45 & 13 & 8 & 45 & 13 & 8 \\
\hline Ferrous $\left(\mathrm{Fe}^{2+}\right)$ & 0.3 & 9 & 2 & 0.3 & 9 & 2 \\
\hline Manganese $\left(\mathrm{Mn}^{2+}\right)$ & 0.1 & 7 & 6 & 0.1 & 7 & 6 \\
\hline Chromium $\left(\mathrm{Cr}^{6+}\right)$ & 0.05 & 8 & 8 & 0.05 & 8 & 8 \\
\hline Ex & $\mathrm{pH}, \mathrm{EC}(\mathrm{l}$ & os $/ \mathrm{cm}), \mathrm{Tl}$ & $\operatorname{dity}(\mathrm{NTU})$ & aining para & $s$ are in $\mathrm{mg} \mathrm{l}^{-1}$ & \\
\hline
\end{tabular}

\section{Assess the Quality of Groundwater by Water Quality Index}

For the determination of WQI during pre- as well as post-monsoon, 9 groundwater quality parameters (Table-2) have been chosen. The WQI values have been determined individually (Fig.-2) on the basis of 9 water quality parameters for each sampling regions (66 sampling regions) for pre- as well as postmonsoon periods in the study region. The measured WQI values in pre-monsoon shows that $7.6 \%$ of the groundwater samples belong to excellent water, $25.7 \%$ good water, $54.5 \%$ poor water, $10.6 \%$ very poor 
water and $1.5 \%$ unfit for drinking in which it was lowest for sampling site 54 and highest for sampling site 47 in the study region whereas in post-monsoon season shows that $4.5 \%$ of the groundwater samples belong to excellent water, $28.7 \%$ good water, $54.5 \%$ poor water and $12.1 \%$ very poor water for drinking in which it was lowest for sampling site 54 and highest for sampling site 47 in the study region. Based on the obtained results in both pre as well as post-monsoon periods, the majority part of the sampling locations was in poor quality and it is probably owing to geological impact, excess utilization of groundwater, the viable release of effluents and lack of seepage of water. Hence, it needs regular monitoring of groundwater quality and also possible treatment measures to recover the quality of water.

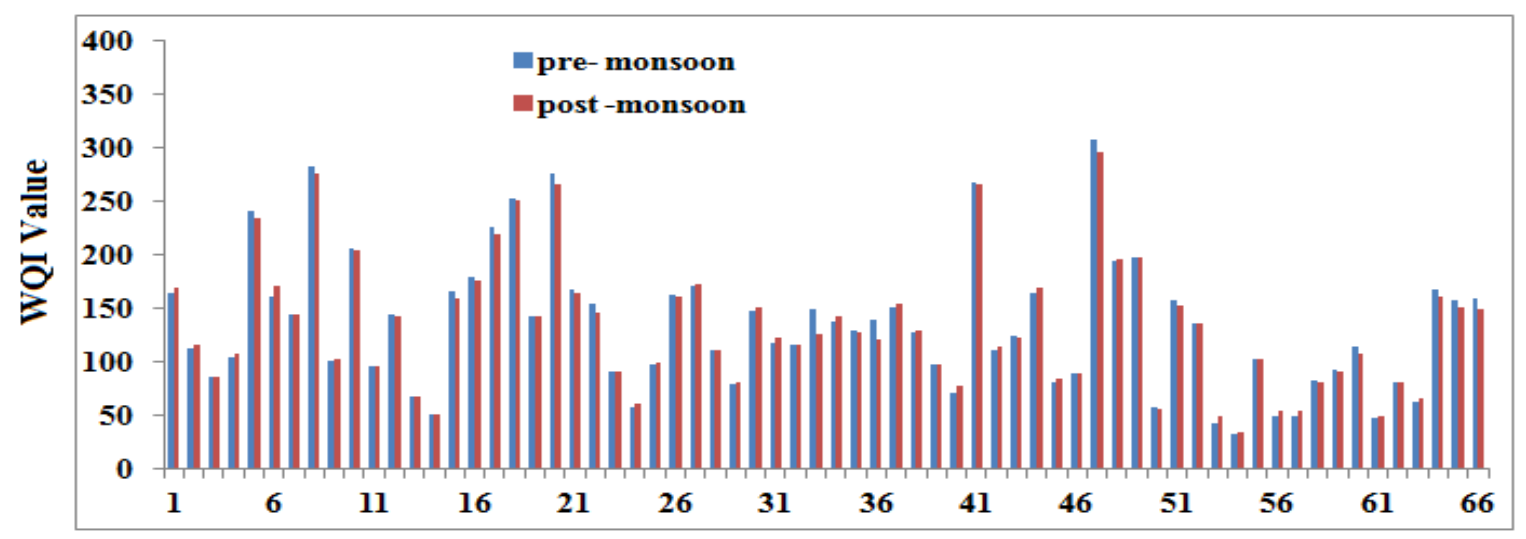

Water sample number

Fig.-2: Graphical Representation of WQI values during Pre-and Post Monsoon Seasons

\section{Correlation Matrix of Various Physicochemical Parameters During Pre- as well as Post-Monsoon}

The systematic studies of correlation and regression coefficients of the groundwater quality parameters were useful to measure the overall groundwater quality as well as to determine the relative concentration of pollutants in groundwater. ${ }^{19}$ Pearson's correlation coefficient (indicated ' $r$ ') is normally useful to find the relationship between the two variables. The parameters having $r>0.5$ or $<-0.5$ are considered important. The correlation coefficients of the physicochemical parameters data of pre-monsoon as well as post-monsoon have been given in Table-7 and Table-8, respectively. In both the pre- as well as postmonsoon periods, strong positive correlations exist between $\mathrm{Ca}^{2+}, \mathrm{Mg}^{2+}, \mathrm{Cl}^{-}, \mathrm{SO}_{4}{ }^{2-}$ and $\mathrm{NO}_{3}^{-}$were observed, which represents that these ions contribute considerably to TDS, TH in the groundwater of this study region. A strong correlation of calcium and magnesium with chloride, sulfate and nitrate ion represents that the groundwater samples have been polluted more by these components due to overexploitation and anthropogenic activities. The main source of calcium, as well as magnesium ions in the groundwater, may owe ion-exchange of minerals among rocks and water.

Table-7: Correlation Matrix Between Water Quality Parameters: Pre-Monsoon

\begin{tabular}{c|c|c|c|c|c|c|c|c|c|c}
\hline & $\mathrm{pH}$ & Turb & $\mathrm{EC}$ & TDS & $\mathrm{TH}$ & $\mathrm{Ca}^{2+}$ & $\mathrm{Mg}^{2+}$ & $\mathrm{Na}^{+}$ & $\mathrm{K}^{+}$ & $\mathrm{TA}$ \\
\hline $\mathrm{pH}$ & 1 & & & & & & & & & \\
\hline Turb & 0.042 & 1 & & & & & & & & \\
\hline $\mathrm{EC}$ & 0.006 & 0.1001 & 1 & & & & & & & \\
\hline $\mathrm{TDS}$ & 0.006 & 0.0994 & 0.999 & 1 & & & & & & \\
\hline $\mathrm{TH}$ & 0.028 & 0.1417 & 0.799 & 0.7946 & 1 & & & & & \\
\hline $\mathrm{Ca} 2+$ & -0.08 & 0.1841 & 0.745 & 0.7454 & 0.8701 & 1 & & & & \\
\hline $\mathrm{Mg} 2+$ & 0.002 & 0.1078 & 0.723 & 0.7241 & 0.9415 & 0.6846 & 1 & & & \\
\hline $\mathrm{Na}+$ & -0.08 & 0.2379 & 0.539 & 0.5398 & 0.5041 & 0.5351 & 0.412 & 1 & & \\
\hline $\mathrm{K}^{+}$ & 0.067 & 0.0935 & -0.02 & -0.0231 & -0.0163 & 0.0653 & -0.06 & 0.150 & 1 & \\
\hline $\mathrm{TA}$ & 0.003 & 0.0106 & 0.006 & 0.007 & 0.0070 & 0.0006 & 0.012 & 0.008 & -0.06 & 1 \\
\hline
\end{tabular}


RASĀYAN J. Chem.

Vol. 12 | No. 4 |1828 - 1838| October - December | 2019

\begin{tabular}{|c|c|c|c|c|c|c|c|c|c|c|}
\hline $\mathrm{F}^{-}$ & 0.151 & -0.0543 & -0.30 & -0.3029 & -0.1992 & -0.2601 & -0.15 & 0.110 & -0.0123 & 0.016 \\
\hline $\mathrm{Cl}^{-}$ & 0.083 & 0.3087 & 0.672 & 0.6729 & 0.7472 & 0.7064 & 0.677 & 0.572 & -0.01 & -0.001 \\
\hline $\mathrm{SO}_{4}{ }^{2-}$ & 0.102 & 0.196 & 0.618 & 0.618 & 0.858 & 0.732 & 0.824 & 0.432 & -0.023 & 0.016 \\
\hline $\mathrm{NO}_{3}^{-}$ & 0.104 & 0.158 & 0.769 & 0.770 & 0.95 & 0.84 & 0.87 & 0.55 & 0.008 & 0.047 \\
\hline $\mathrm{Fe}^{2+}$ & 0.007 & -0.071 & 0.697 & 0.697 & 0.832 & 0.728 & 0.760 & 0.298 & -0.038 & 0.015 \\
\hline $\mathrm{Mn}^{2+}$ & 0.040 & 0.004 & 0.46 & 0.46 & 0.66 & 0.546 & 0.643 & 0.236 & 0.001 & 0.001 \\
\hline $\mathrm{Cr}^{6+}$ & 0.149 & -0.028 & 0.277 & 0.276 & 0.200 & 0.11 & 0.258 & 0.099 & -0.031 & -0.140 \\
\hline & $\mathrm{F}^{-}$ & $\mathrm{Cl}^{-}$ & $\mathrm{SO}_{4}{ }^{2-}$ & $\mathrm{NO}_{3}{ }^{-}$ & $\mathrm{Fe}^{2+}$ & $\mathrm{Mn}^{2+}$ & $\mathrm{Cr}^{6+}$ & \multirow{8}{*}{\multicolumn{3}{|c|}{$\begin{array}{c}\text { Note: } \\
\text { Turb. = Turbidity } \\
\text { TDS = Total Dissolved } \\
\text { Solids } \\
\text { TH= Total Hardness } \\
\text { TA=Total alkalinity }\end{array}$}} \\
\hline $\mathrm{F}^{-}$ & 1 & & & & & & & & & \\
\hline $\mathrm{Cl}^{-}$ & -0.082 & 1 & & & & & & & & \\
\hline $\mathrm{SO}_{4}{ }^{2-}$ & -0.104 & 0.738 & 1 & & & & & & & \\
\hline $\mathrm{NO}_{3}{ }^{-}$ & -0.12 & 0.710 & 0.823 & 1 & & & & & & \\
\hline $\mathrm{Fe}^{2+}$ & -0.239 & 0.608 & 0.700 & 0.789 & 1 & & & & & \\
\hline $\mathrm{Mn}^{2+}$ & -0.12 & 0.478 & 0.542 & 0.657 & 0.818 & 1 & & & & \\
\hline $\mathrm{Cr}^{6+}$ & -0.216 & 0.171 & 0.115 & 0.191 & 0.43 & 0.49 & 1 & & & \\
\hline
\end{tabular}

Table-8: Correlation Matrix Between Water Quality Parameters: Post-Monsoon

\begin{tabular}{|c|c|c|c|c|c|c|c|c|c|c|}
\hline & $\mathrm{pH}$ & Turb & $\mathrm{EC}$ & TDS & $\mathrm{TH}$ & $\mathrm{Ca}^{2+}$ & $\mathrm{Mg}^{2+}$ & $\mathrm{Na}^{+}$ & $\mathrm{K}^{+}$ & TA \\
\hline $\mathrm{pH}$ & 1 & & & & & & & & & \\
\hline Turb & 0.154 & 1 & & & & & & & & \\
\hline EC & 0.005 & -0.100 & 1 & & & & & & & \\
\hline TDS & 0.005 & -0.100 & 0.999 & 1 & & & & & & \\
\hline TH & -0.021 & 0.003 & 0.794 & 0.7950 & 1 & & & & & \\
\hline $\mathrm{Ca}^{2+}$ & -0.097 & -0.0256 & 0.719 & 0.7193 & 0.8920 & 1 & & & & \\
\hline $\mathrm{Mg}^{2+}$ & 0.033 & 0.0368 & 0.751 & 0.7517 & 0.9367 & 0.6830 & 1 & & & \\
\hline $\mathrm{Na}^{+}$ & 0.046 & 0.1501 & 0.584 & 0.5841 & 0.5130 & 0.5504 & 0.425 & 1 & & \\
\hline $\mathrm{K}^{+}$ & 0.155 & 0.0771 & -0.005 & -0.0057 & -0.0100 & 0.0129 & -0.020 & 0.280 & 1 & \\
\hline TA & 0.146 & 0.1870 & 0.131 & 0.1309 & 0.1457 & 0.0374 & 0.200 & 0.122 & -0.037 & 1 \\
\hline $\mathrm{F}^{-}$ & 0.093 & 0.0552 & -0.232 & -0.2327 & -0.2019 & -0.2427 & -0.146 & 0.119 & 0.046 & 0.238 \\
\hline $\mathrm{Cl}^{-}$ & 0.060 & 0.1388 & 0.665 & 0.6659 & 0.7523 & 0.7033 & 0.685 & 0.581 & -0.005 & -0.019 \\
\hline $\mathrm{SO}_{4}{ }^{2-}$ & 0.080 & 0.031 & 0.622 & 0.623 & 0.851 & 0.740 & 0.813 & 0.438 & -0.033 & 0.083 \\
\hline $\mathrm{NO}_{3}{ }^{-}$ & 0.071 & 0.035 & 0.670 & 0.671 & 0.901 & 0.809 & 0.835 & 0.510 & 0.011 & 0.100 \\
\hline $\mathrm{Fe}^{2+}$ & -0.04 & $\begin{array}{l}-0.19 \\
\end{array}$ & 0.689 & 0.689 & 0.765 & 0.68 & 0.715 & 0.28 & -0.086 & 0.05 \\
\hline $\mathrm{Mn}^{2+}$ & 0.034 & -0.09 & 0.43 & 0.43 & 0.67 & 0.55 & 0.63 & 0.24 & 0.02 & 0.01 \\
\hline \multirow[t]{2}{*}{$\mathrm{Cr}^{6+}$} & 0.03 & $\begin{array}{l}-0.14 \\
\end{array}$ & 0.46 & 0.46 & 0.33 & 0.23 & 0.36 & 0.32 & 0.080 & 0.06 \\
\hline & $\mathrm{F}^{-}$ & $\mathrm{Cl}^{-}$ & $\mathrm{SO}_{4}^{2-}$ & $\mathrm{NO}_{3}{ }^{-}$ & $\mathrm{Fe}^{2+}$ & $\mathrm{Mn}^{2+}$ & $\mathrm{Cr}^{6+}$ & \multirow{8}{*}{\multicolumn{3}{|c|}{$\begin{array}{l}\text { Note: } \\
\text { urb. = Turbidity } \\
\text { S =Total Dissolved } \\
\text { Solids } \\
\text { I= Total Hardness } \\
\text { = Total alkalinity }\end{array}$}} \\
\hline $\mathrm{F}^{-}$ & 1 & & & & & & & & & \\
\hline $\mathrm{Cl}^{-}$ & -0.057 & 1 & & & & & & & & \\
\hline $\mathrm{SO}_{4}^{2-}$ & -0.097 & 0.736 & 1 & & & & & & & \\
\hline $\mathrm{NO}_{3}^{-}$ & -0.082 & 0.702 & 0.826 & 1 & & & & & & \\
\hline $\mathrm{Fe}^{2+}$ & -0.17 & 0.58 & 0.669 & 0.699 & 1 & & & & & \\
\hline $\mathrm{Mn}^{2+}$ & -0.06 & 0.46 & 0.56 & 0.614 & 0.68 & 1 & & & & \\
\hline $\mathrm{Cr}^{6+}$ & 0.11 & 0.29 & 0.185 & 0.29 & 0.45 & 0.48 & 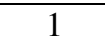 & & & \\
\hline
\end{tabular}

CONCLUSION

The groundwater quality in terms of drinking purpose in the study region was assessed by the WQI method and it is aptly helpful and useful in the evaluation and supervision of the groundwater quality. In this study, the variations in the WQI values were studied and there is an insignificant difference at pre- as well as post-monsoon seasons. Based on WQI data, 54.5\% of the groundwater sampling locations in the study region showed poor water. The high WQI values in groundwater samples in this region were mainly owing to the presence of a major amount of total hardness causing ions $\left(\mathrm{Ca}^{2+}, \mathrm{Mg}^{2+}\right)$ and these are beyond their desirable limits. According to the correlation matrix, the $\mathrm{Ca}^{2+}$ and $\mathrm{Mg}^{2+}$ were strongly correlated with $\mathrm{Cl}^{-}, \mathrm{SO}_{4}{ }^{2-}$ and $\mathrm{NO}_{3}{ }^{-}$which reveal that the groundwater samples in the study region have been vastly 
polluted owing to lack of seepage of water and anthropogenic activities. To recuperate the groundwater quality of the study region, treatment measures were required to enhance the groundwater potential both qualitatively and quantitatively.

\section{REFERENCES}

1. H. L. Yadav and A. Jamal, Rasayan Journal of Chemistry, 11(1), 46(2018), DOI: 10.7324/RJC.2018.1111961

2. R. Khan and D. C. Jhariya, Journal of Geological Society of India, 90, 69(2017), DOI: 10.1007/s12594-017-0665-0

3. Y. Rakesh Kumar and M. R. Augur, Rasayan Journal of Chemistry, 11(2),537(2018), DOI:10.31788/RJC.2018.1122089

4. G. Bhalla, A. Kumar and B.Ajay, Asian Journal of Water Environment and Pollution, 8(1), 41(2011).

5. C. Sakuntala and P. Pulak Kumar, Rasayan Journal of Chemistry, 10(4), 1424(2017), DOI:10.7324/RJC.2017.1041741

6. N. Subba Rao, Environmental Geology, 49, 413(2006), DOI:10.1007/s00254-005-0089-9

7. A. Zubair, A. Hussain, M.A. Farooq and H.N. Abassi, Environmental Monitoring and Assessment, 162, 427 (2010).

8. P. S. Bytyçi, H. S. Çadraku, F. N. Zhushi Etemi, M.A. Ismaili, O.B. Fetoshi and A.M. Shala Abazi, Rasayan Journal of Chemistry, 11(2), 653(2018), DOI: 10.31788/RJC.2018.1123015

9. Deepak Kumar, Vinay Kumar and Sangeeta Kumari, Rasayan Journal of Chemistry, 11(4), 1477(2018), DOI: 10.31788/RJC.2018.1143075

10. Adnan Khan and F.R. Qureshi, Asian Journal of Water Environment and Pollution, 15(1), 41(2018), DOI: $10.3233 / \mathrm{AJW}-180004$

11. I. A. Talalaj, Environment Monitoring and Assessment, 186, 3673(2014), DOI:10.1007/s10661-0143649-1.

12. Ramita Varshney and Aarif Jamal, Rasayan Journal of Chemistry,12(1),251(2019), DOI: 10.31788/RJC.2019.1215056

13. M. V. Subba Rao, V. Dhilleswararao and B.S.A. Andrews, International Research Journal of Environment Sciences, 1, 13(2012).

14. R. Varshney and A. Jamal, Rasayan Journal of Chemistry, 11(3), 1177(2018), DOI:10.31788/RJC.2018.1134023

15. R. Shabbir, and S.S. Ahmad, Arabian Journal for Science and Engineering, 40(7), 2033(2015), DOI 10.1007/s13369-015-1697-7

16. BIS-Bureau of Indian standards -Drinking water specifications IS 10500:2012.

17. S. K. Kumar, A. Logeshkumaran, N. S. Magesh, P. S. Godson and N. Chandrasekar, Applied Water Science, 5(4), 335(2015), DOI: 10.1007/s13201-014- 0196-4

18. K. Prabhu and R. Sivakumar, Rasayan Journal of Chemistry, 11(2),735(2018), DOI:10.31788/RJC.2018.1121837

19. M. Jeyaraj, K. Ramakrishnan, S. Arunachalam and P. N. Magudeswarani, Asian Journal of Chemistry, 28(7), 1469(2016), DOI: 10.14233/ajchem.2016.19719

[RJC-5394/2019] 